\title{
Features of the Oxygen and Sulfide Vertical Distribution in the Black Sea Based on the Expedition Data Obtained by Marine Hydrophysical Institute in 1995-2015
}

\author{
S. I. Kondratev*, A. V. Vidnichuk \\ Marine Hydrophysical Institute, Russian Academy of Sciences, Sevastopol, Russian Federation \\ *e-mail: skondratt@mail.ru
}

\begin{abstract}
Discussed are the features of the oxygen and sulfide vertical distribution resulted from the expedition data obtained by Marine Hydrophysical Institute in the northern part of the Black Sea (within the economic zone of Russia) in 1995-2015. In course of the last 20 years, the upper boundary of the sulfide zone in this area, defined by the sulfide isoline $3 \mu \mathrm{M}$, did not change its position in the scale of relative density and is located on $\sigma_{t}=16.10-16.15 \mathrm{~kg} / \mathrm{m}^{3}$. Closer to the northwest shelf (in the area of the Sevastopol anticyclone), the hydrogen sulfide isoline $3 \mu \mathrm{M}$ is slightly lifted to $\sigma_{t}=15.9$ $16.0 \mathrm{~kg} / \mathrm{m}^{3}$; there is a single case when its position was recorded at $\sigma_{t}=15.85 \mathrm{~kg} / \mathrm{m}^{3}$. Position of the suboxic zone upper boundary (the threshold oxygen isoline $10 \mu \mathrm{M}$ ) is characterized by spatial and temporal variability. During four expeditions in 2009-2013, in the region of the northwestern shelf the suboxic zone upper boundary was located, regardless of the season, within $\sigma_{t}=15.6-15.7 \mathrm{~kg} / \mathrm{m}^{3}$. In November, 2013 in the deep sea part, the threshold oxygen isoline $10 \mu \mathrm{M}$ was located on $\sigma_{t}=$ $15.7 \mathrm{~kg} / \mathrm{m}^{3}$, whereas in November, 2015 it was considerably higher: on $\sigma_{t}=15.35 \mathrm{~kg} / \mathrm{m}^{3}$. The change of location of the threshold oxygen isoline $10 \mu \mathrm{M}$ observed in 1995-2015 provides no possibility to assess unambiguously alteration of the suboxic zone thickness in the central part of the sea. Thus within the depths 1750-2000 m in the Black Sea, no significant increase of the sulfide content in 1995-2015 has been recorded.
\end{abstract}

Keywords: oxygen, sulfide, suboxic zone, hydrogen sulfide zone, Black Sea.

Acknowledgments: the investigation is carried out within the framework of the state task on the theme № 0827-2018-0003 “Fundamental studies of the oceanologic processes conditioning the marine environment state and evolution under the impact of natural and anthropogenic factors based on the methods of observations and modeling (code "Oceanological processes") and the theme № 08282018-0009 "Physical mechanisms of formation of spatial-temporal structural features of hydrochemical characteristics in different areas of the Black Sea active layer" (in the joint project "Interaction of physical, chemical and biological processes in the World Ocean") state registration № AAAA-A18118013190197-7 according to the state task № 007-00080-18-00 on 2018 and on the planning period on 2019 and 2020 according to the research plan of FSBSI "A.O. Kovalevsky Institute of Marine Biological Researches, RAS” on 2018 - 2020.

For citation: Kondratev, S.I. and Vidnichuk, A.V., 2018. Features of the Oxygen and Hydrogen Sulfide Vertical Distribution in the Black Sea Based on the Expedition Data Obtained by Marine Hydrophysical Institute in 1995-2015. Physical Oceanography, [e-journal] 25(5), pp. 390-400. doi:10.22449/0233-7584-2018-5-390-400.

DOI: $10.22449 / 1573-160 X-2018-4-390-400$

(C) 2018, S. I. Kondratev, A. V. Vidnichuk

(C) 2018, Physical Oceanography

\section{Introduction}

Location of the sulfide zone in the Black Sea was systematically studied by the Soviet and, later, Russian oceanologists in the 1970s-1990s. In the 90s, comprehensive analysis of the obtained results gradually brought to development and application of the relative density $\sigma_{t}$-scale in order to make the data interpretation more logical and simple [1-12]. 
Since the early 90s, large-scale expeditions in the Black Sea covering the area from the Danube mouth to the Caucasian coast transformed into the studies of individual countries within their economic zones. For Marine Hydrophysical Institute (MHI), the $33^{\text {rd }}$ cruise of the R/V "Professor Kolesnikov" in spring, 1995 became the final many-sided expedition in the Black Sea. Its results were discussed in the preprint [13]. The next complex expedition in the Black Sea (numerous group of the MHI scientists took part in it) was a cruise of the Bulgarian $\mathrm{R} / \mathrm{V}$ “Akademik" in the region of the Sevastopol anticyclone in May, 2004. The obtained data analyzed the location of the upper and lower boundaries of the suboxic zone (the lower boundary of this zone is the upper boundary of the sulfide zone) above the continental slope [14].

The subsequent MHI expeditionary investigations were of a shortterm occasional character. The main area of researches reduced up to the northwestern shelf (NWS) of the Black Sea [15-17]. In the deep-sea part, the continental slope in the region of the Sevastopol anticyclone was studied rather constantly.

Reunification of Russia and Crimea, and the institute's transfer to the Russian Academy of Sciences started a new stage of expeditionary researches of MHI. In autumn, 2015 a joint expedition of MHI and the Institute of Oceanology (Moscow) was run in the region of the "century" section Cape Chersonese - Bosporus Strait. The expeditionary research in the deep-sea area along the Crimea coast and within the economic zone of Russia was planned for 2016-2017. Elaboration of a strategy for subsequent hydrochemical studies in the Black Sea laid down in MHI requires systematization of separate incomplete results obtained by the institute scientists after 2004. They are planned to be subsequently compared with the data that will be gotten from the future studies of the suboxic and sulfide zones. The present paper deals with this problem.

\section{Materials and methods}

The scheme of the MHI hydrochemical stations during the cruises in 20092015 is shown in Fig. 1. Sampling for chemical analysis was done using a 12-bottle cassette of a CTD-probe (produced by Sea-Bird Electronics, Inc.) at the depth of certain isopycnic surfaces. As a rule, the samples for sulfide were taken at the maximum depth and then along the $\sigma_{t}=16.30 ; 16.20 ; 16.15 ; 16.10 ; 16.05 ; 16.00$; $15.90 ; 15.80 ; 15.60 ; 15.40$ and $15.20 \mathrm{~kg} / \mathrm{m}^{3}$, which covered the suboxic zone completely. At the utmost southwestern station on the section Cape Chersonese Bosporus Strait, the samples for sulfide were taken at 28 horizons: slightly less than $2000 \mathrm{~m}$, then in every $100 \mathrm{~m}$ and, finally, at the $\sigma_{t}$ cited above.

Such sampling permitted to define location of the upper boundaries of the intermediate suboxic layer and the sulfide zone, as well as the suboxic layer thickness, resolution is up to $\Delta \sigma_{t}=0.05$. It corresponds to the accuracy equal approximately to $5 \mathrm{~m}$, according to the depth scale.

The sulfide content was defined by the iodometric method assuming that iodine consumption on the $\sigma_{t}=15.8 \mathrm{~kg} / \mathrm{m}^{3}$ is equal to zero and the oxygen concentration - by the Winkler method modified for sampling with low oxygen content according to the method [18]. In both cases, 15 minutes before sampling, the $200 \mathrm{ml}$ volumetric flasks for fixing sulfide and the oxygen bottles with a narrow neck were flushed with argon. 


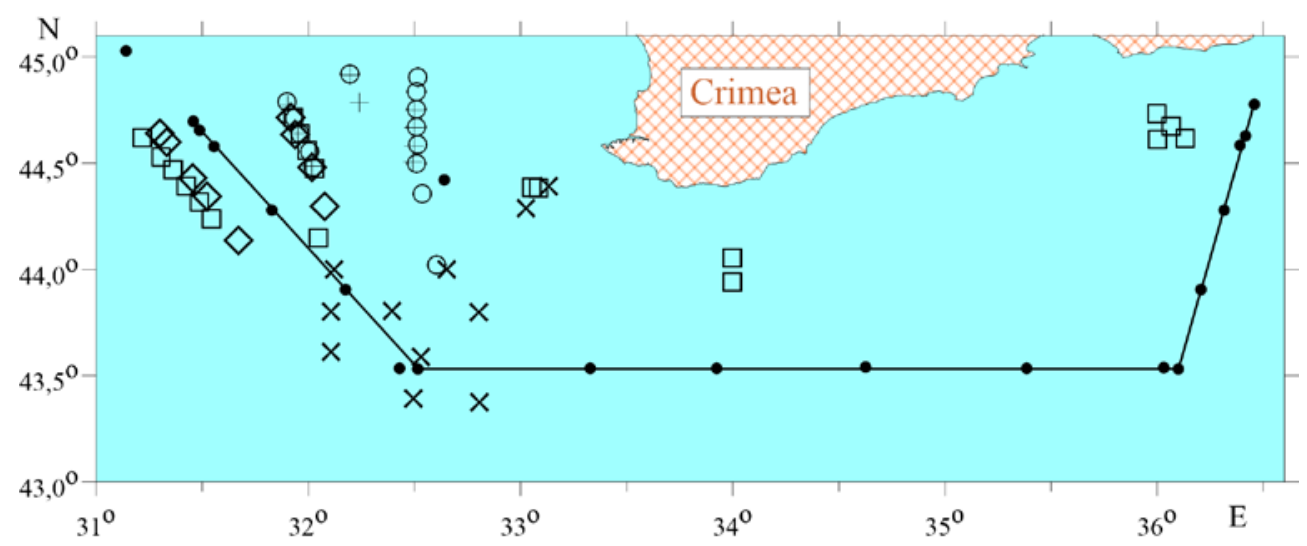

Fig. 1. Scheme of the stations where the $\mathrm{H}_{2} \mathrm{~S}$ and $\mathrm{O}_{2}$ vertical profiles were done: + is R/V "Sapfir", May, 2009; $\diamond$ is R/V "Professor Vodyanitsky", October, 2010; $\square$ is R/V "Professor Vodyanitsky", August, 2011; o is R/V "Professor Vodyanitsky", September, 2013; • is R/V "Maria S. Merian", November, 2013; × is R/V "Professor Vodyanitsky", November, 2015. Solid line marks the section carried out in November, 2013

\section{Discussion of the results}

The relatively detailed studies of the R/V "Akademik" in the region of the quasi-stationary Sevastopol anticyclone in 2004 showed that in the areas of the shelf transformation to the continental slope, the sulfide isoline $3 \mu \mathrm{M}$ was located on the $\sigma_{t}=15.88 \mathrm{~kg} / \mathrm{m}^{3}$, whereas in the deep sea region the same sulfide concentrations were observed on the $\sigma_{t}=16.05 \mathrm{~kg} / \mathrm{m}^{3}$ [14]. Thus, it seems logical to consider individually the vertical profiles of oxygen and sulfide obtained in the region of the Sevastopol anticyclone continental slope in 2009-2013 and those obtained in the central deep-sea part in 2013-2015 and shown in Fig. 2, 3, respectively.

First of all, Fig. 2 demonstrates a good coincidence of configurations of the sulfide content data resulted from different surveys. That, in fact, permits to analyze all the data. The results obtained in May, 2009 do not fall into the pattern as they show that the sulfide concentrations within the interval $\sigma_{t}=16.0$ $16.4 \mathrm{~kg} / \mathrm{m}^{3}$ in the region of the continental slope at the NWS edge were slightly higher than those observed in all the other regions. This fact confirms the conclusion [14] that the sulfide isolines at the beginning of the continental slope go up to the higher $\sigma_{t}$, but it requires more scrupulous studies. In particular, it seems reasonable to include several stations where the depths correspond to the $\sigma_{t}$ location near $16.1-16.2 \mathrm{~kg} / \mathrm{m}^{3}$ (approximately at $150-170 \mathrm{~m}$ ) in the subsequent investigations of the vertical structures of dissolved oxygen and sulfide. The sampling interval should be $\Delta \sigma_{t}=0.05 \mathrm{~kg} / \mathrm{m}^{3}$ up to the $\sigma_{t}=15.7 \mathrm{~kg} / \mathrm{m}^{3}$.

Fig. 3 provides a more detailed pattern of the oxygen and sulfide vertical distribution between the $\sigma_{t}=15.0-16.3 \mathrm{~kg} / \mathrm{m}^{3}$ where the suboxic zone is located; its upper boundary coincides with the oxygen isoline $10 \mu \mathrm{M}$ (in some papers $20 \mu \mathrm{M}$ ), and the lower one - with the sulfide isoline $3 \mu \mathrm{M}$ (in some papers $5 \mu \mathrm{M})$. 


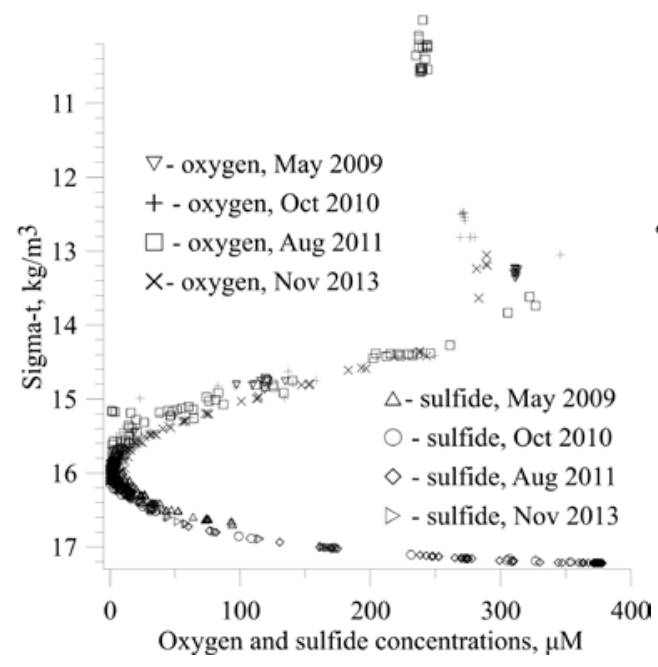

$a$

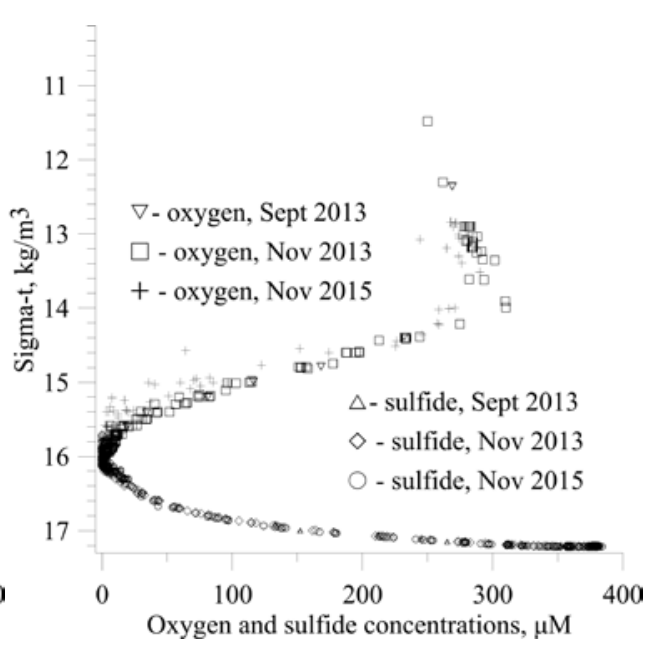

$b$

Fig. 2. Vertical profiles of oxygen and sulfide in the region of the Sevastopol anticyclone in 20092013 (a) and in the deep part of the Black Sea in 2013-2015 (b)

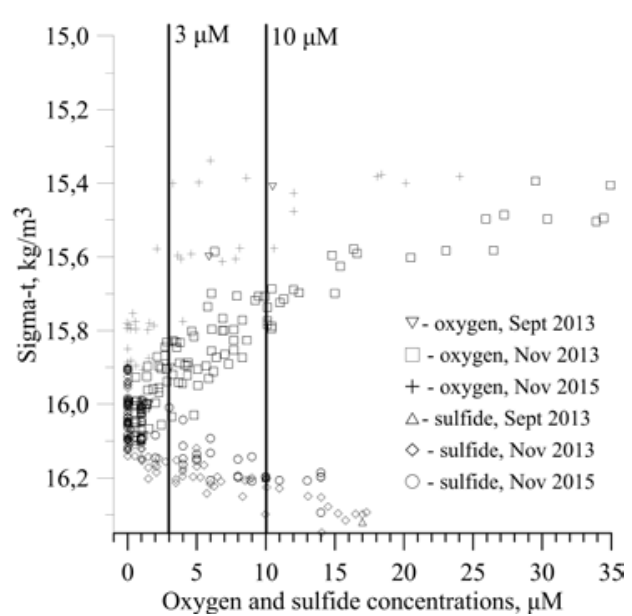

$a$

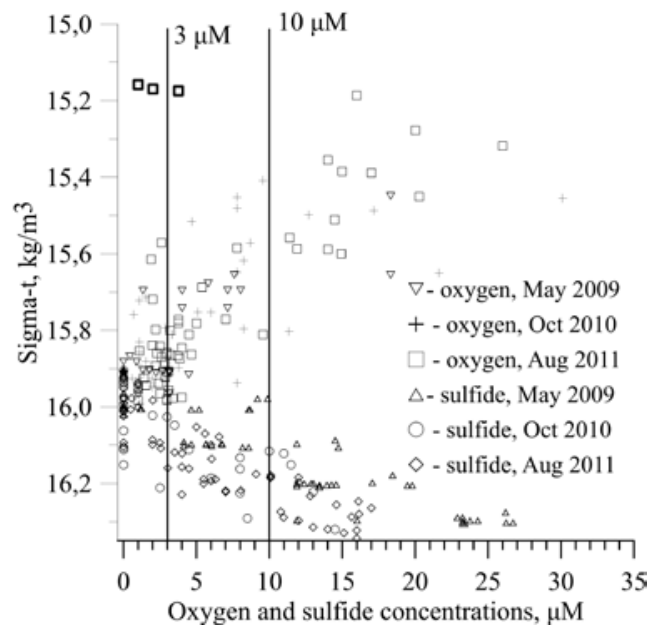

$b$

Fig. 3. Vertical profiles of oxygen and sulfide in the region of the Sevastopol anticyclone in 20092011 (a) and in the deep part of the Black Sea in 2013-2015 (b)

Fig. 3, a shows that in August, 2011, at the most western station, located at the beginning of the continental slope on the depth $120 \mathrm{~m}$ (see Fig. 1), an almost zero oxygen content was recorded at the $\sigma_{t}=15.2 \mathrm{~kg} / \mathrm{m}^{3}$. This corresponds to the highest location of the suboxic zone upper boundary revealed in course of the studies.

Except for the already above-mentioned increased sulfide concentrations observed in May, 2009, Fig. 3 also shows that the oxygen concentrations exceeding $10 \mu \mathrm{M}$ were recorded above the shelf edge at the $\sigma_{t}=15.7 \mathrm{~kg} / \mathrm{m}^{3}$ only in November, 2013, whereas in the deep-sea part such values were observed 
regularly. As for the $\sigma_{t} \geq 15.8 \mathrm{~kg} / \mathrm{m}^{3}$, the oxygen content at them was lower than $10 \mu \mathrm{M}$ in all the performed surveys.

The suboxic zone configuration and dimensions can be defined more accurately by the oxygen and sulfide vertical distributions at single sections. Thus, as for the Sevastopol anticyclone region, distribution of these elements on the sections perpendicular to the shelf edge in 2009-2011 is represented in Fig. 4. In May, 2009, on two sections, the sulfide isoline $3 \mu \mathrm{M}$ was located above the $\sigma_{t}=$ $=16.0 \mathrm{~kg} / \mathrm{m}^{3}$ rising (in the maximum case) up to $\sigma_{t}=15.85 \mathrm{~kg} / \mathrm{m}^{3}$ (Fig. $4, a$ ). These data coincide with the results of the studies carried out from board the R/V “Akademik” in May, 2004 [14].

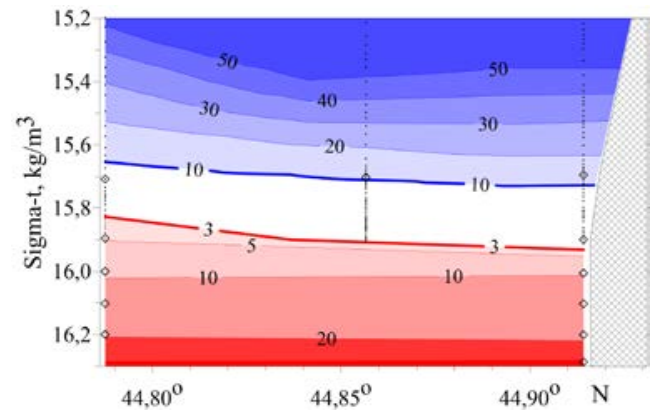

$a$

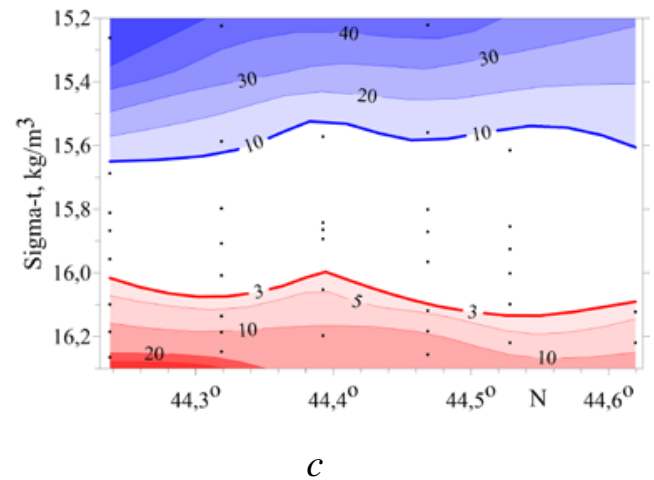

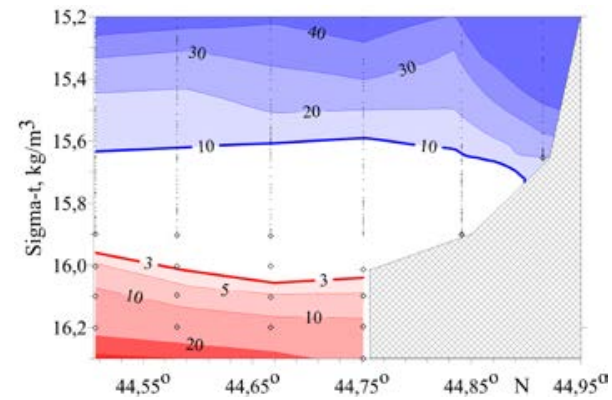

$b$

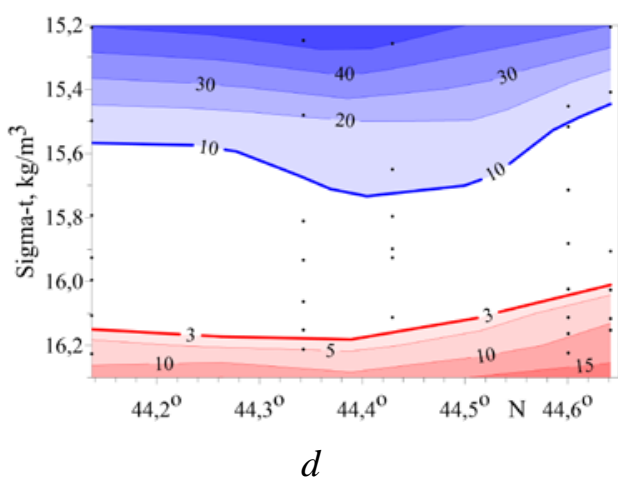

Fig. 4. Vertical distribution of the oxygen and sulfide concentrations, $\mu \mathrm{M}$, on the Sevastopol anticyclone sections in May, 2009 (the meridian $32^{\circ} \mathrm{E}(a)$, the meridian $32.5^{\circ} \mathrm{E}(\mathrm{b})$ ), August, 2011 (c) and October, $2010(d) ; \diamond$ and $\bullet$ denote the horizons of sampling

Most likely, the above noted sulfide isoline elevation (in the density scale) represents a seasonal phenomenon since in the very same region in summer, 2011 the sulfide isoline $3 \mu \mathrm{M}$ was located below the $\sigma_{t}=16.0 \mathrm{~kg} / \mathrm{m}^{3}$, and in autumn, 2010 - just a little lower than the $\sigma_{t}=16.1 \mathrm{~kg} / \mathrm{m}^{3}$. In other words, during transition from spring to autumn, the gradual deepening of the sulfide isoline $3 \mu \mathrm{M}$ is observed. However, one cannot exclude influence of water dynamics (for example, various phases of the Sevastopol anticyclone development [19-21]) on location of the upper boundary of the sulfide zone in this region. 
On three sections the upper boundary of the suboxic zone (oxygen isoline $10 \mu \mathrm{M}$ ) was located approximately at the $\sigma_{t}=15.6 \mathrm{~kg} / \mathrm{m}^{3}$ (Fig. 4, $a$ ). Fig. 4, $a, b$ shows increase of the oxygen content in the northern part of the sections above the continental slope. This feature of the oxygen distribution was revealed due to application of the oxygen sensor, which determined oxygen concentration with the resolution $0.5 \mathrm{~m}$. But after 2009 it was not used that resulted in rougher and less reliable distributions.

In November, 2015 the "century" section Cape Chersonese - Bosporus Strait in the central part of the Black Sea was investigated. The parameters of its suboxic zone can be compared with the long-term data [6] (Fig. 5).
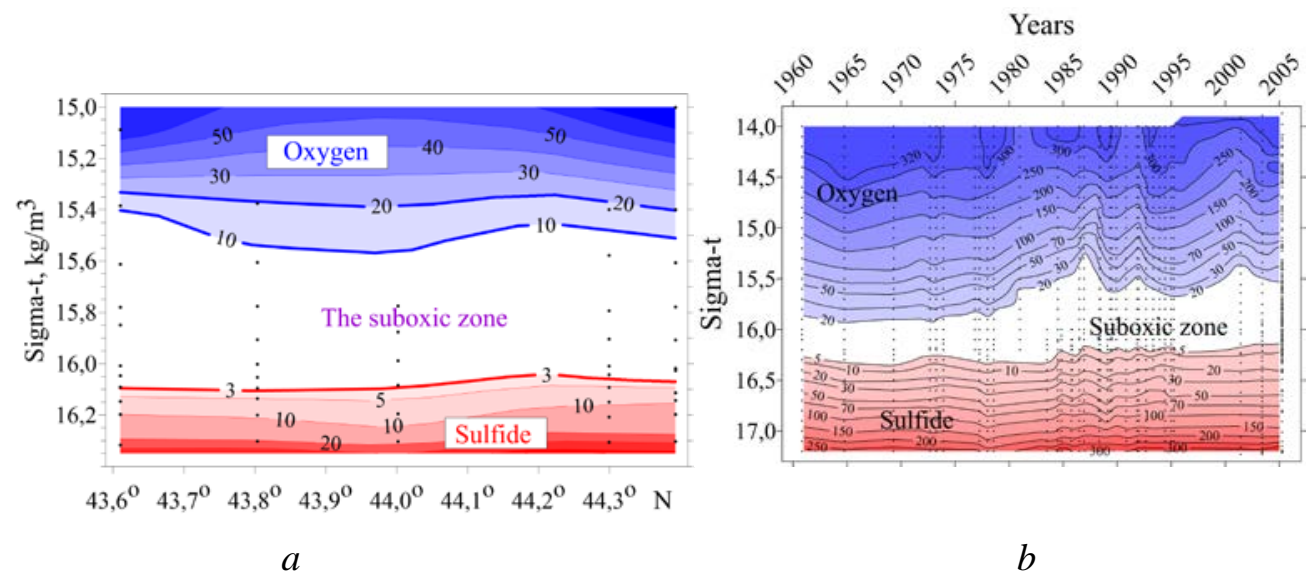

Fig. 5. Vertical distribution of the oxygen and sulfide concentrations, $\mu \mathrm{M}$, on the "century" section Cape Chersonese - Bosporus Strait in 2015 (a) and the one based on the multi-year data [6] (b)

Fig. 5 shows that in 2015 the lower boundary of the suboxic zone, i.e. the sulfide isoline $3 \mu \mathrm{M}$, was within the $\sigma_{t}=16.10-16.15 \mathrm{~kg} / \mathrm{m}^{3}$ (the distance between them, according to the depth scale, is about $5 \mathrm{~m}$ ). The same position of $3 \mu \mathrm{M}$ sulfide isoline was observed on the long-term data given in [6] (Fig. 5). According to the scientific literature data, the approximately same position of the sulfide isoline $3 \mu \mathrm{M}$ was observed to the east and west off the "century" section Cape Chersonese - Bosporus Strait: in the northwest - at $\sigma_{t}=16.12-16.15 \mathrm{~kg} / \mathrm{m}^{3}$, in the southeast - at $\sigma_{t}=16.10-16.20 \mathrm{~kg} / \mathrm{m}^{3}$ [22-24]. Such long-term and spatial stability of location of the suboxic zone lower boundary is explained by sulfide oxidation due to the oxygen-containing Marmara Sea water inflow through the Bosporus Strait, whereas the vertical oxygen flow provides oxidation only of $\sim 5 \%$ of sulfide rising from the sea depth [10].

As for location of the suboxic zone upper boundary, it is characterized by temporal variability. This is confirmed both by the long-term data (Fig. 5) and the results of the MHI observations in 2009-2015. So, in 2009-2011 in the Sevastopol anticyclone region, the oxygen isoline $10 \mu \mathrm{M}$ was located on the $\sigma_{t}=15.60$ $15.65 \mathrm{~kg} / \mathrm{m}^{3}$ (Fig. 4), and in November, 2015 on the "century" section Cape Chersonese - Bosporus Strait it was much higher - on the $\sigma_{t}=15.35-15,40 \mathrm{~kg} / \mathrm{m}^{3}$ (Fig. 5). 
The most detailed (the oxygen sensor with the vertical resolution $0.5 \mathrm{~m}$ was used) and extensive (the whole northern part of the Black Sea - in Fig. 1 this section is shown by the solid line) investigation of the suboxic zone upper and lower boundaries was got in the $33^{\text {rd }}$ cruise of the R/V "Maria S. Merian" in November, 2013 (Fig. 6, a).
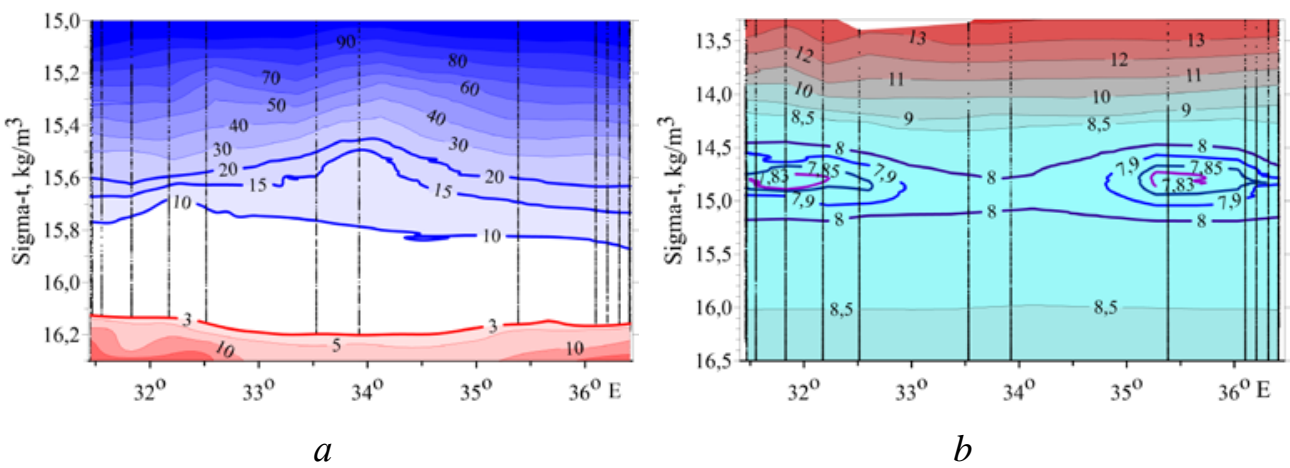

Fig. 6. Location of the upper and lower boundaries of the suboxic zone $(a)$ and the cold intermediate layer $(b)$ on the section from the northwestern shelf (on the left) up to the northeastern one (on the right) in November, 2013

The sulfide isoline $3 \mu \mathrm{M}$, as well on for the previously considered sections, was located within a very narrow interval between the $\sigma_{t}=16.12-16.15 \mathrm{~kg} / \mathrm{m}^{3}$. The oxygen isoline $10 \mu \mathrm{M}$ is characterized by its higher location in the section western part - at $\sigma_{t}=15.75 \mathrm{~kg} / \mathrm{m}^{3}$ than in the section eastern part - at $\sigma_{t}=15.85 \mathrm{~kg} / \mathrm{m}^{3}$. Most likely, this is due to more intensive oxygen consumption for oxidation of suspended organic matter. Its high content in the NWS waters is provided by the freshwater runoff, which ensures the phytoplankton growth and subsequent death processes.

The vertical temperature distribution in the $\sigma_{t}$ scale was analyzed for the section across the northern Black Sea (Fig. 6, b). It exhibits presence of two CIL cores in the western and eastern parts with the minimum temperature $7.83^{\circ} \mathrm{C}$ and absence of such a core (i. e. CIL weakening) in the central part at the longitude 34 E.

These features of CIL (the thicker the layer and lower the temperature, the higher the oxygen content in it) did not affect location of the oxygen isoline $10 \mu \mathrm{M}$, but became quite well pronounced in position of the oxygen isolines within the 15$50 \mu \mathrm{M}$ range: these isolines were elevated at the longitude $34^{\circ} \mathrm{E}$ as compared to the data of the nearest stations. In other words, weakening of CIL and, consequently, decrease in supply of the underlying layers with oxygen resulted in diminution of the oxygen content in them.

The values of the sulfide maximum concentrations in the Black Sea revealed in different expeditions should be considered as an individual problem. Table and Fig. 7 represent the data obtained in 2010-2015. It follows from these data that at the depths exceeding $1700 \mathrm{~m}$, where practically no gradient in the vertical distributions of salinity, temperature and sulfide concentrations is observed [25], the concentration values should constitute about $380 \mu \mathrm{M}$. This exceeds 
significantly the values observed in the 1960-1970s, but does not differ from the values typical of the sulfide concentration at the depth about $2000 \mathrm{~m}$ in the 19801990s [10]. Thus, the drawn conclusion implies that in course of previous 20 years no significant increase of the sulfide content in the Black Sea near-bottom waters was recorded.

\section{Maximum sulfide concentrations revealed in the MHI expeditions in 2010-2016}

\begin{tabular}{l|c|c|c}
\hline \multicolumn{1}{c|}{ Period } & Depth, $\mathrm{m}$ & Relative density, $\mathrm{kg} / \mathrm{m}^{3}$ & Concentration, $\mu \mathrm{M}$ \\
\hline October, 2010 & 1743 & 17.219 & 378 \\
August, 2011 & 1250 & 17.205 & 354 \\
September, 2013 & 1750 & 17.220 & 379 \\
November, 2013 & 2136 & 17.206 & 382 \\
November, 2015 & 1801 & 17.216 & 384 \\
\hline
\end{tabular}

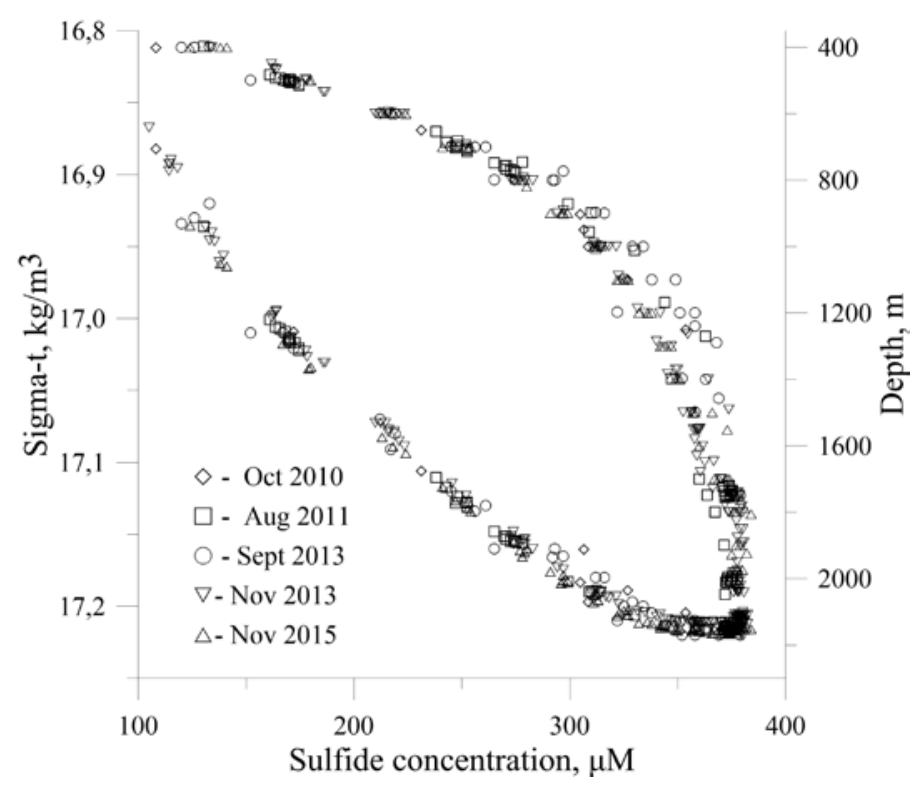

Fig. 7. Vertical distribution of sulfide in 2009-2016 on the depths below $400 \mathrm{~m}$ according to the scales of relative density (the lower graph) and depth (the upper graph)

\section{Conclusions}

In course of the past 20 years, the sulfide zone upper boundary, defined by the sulfide isoline $3 \mu \mathrm{M}$, has not changed its location in the northern part of the Black Sea and is still at the $\sigma_{t}=16.10-16.15 \mathrm{~kg} / \mathrm{m}^{3}$. Closer to the NWS, in the Sevastopol anticyclone region the sulfide isoline $3 \mu \mathrm{M}$ rises to $\sigma_{t}=15.9-16.0 \mathrm{~kg} / \mathrm{m}^{3}$; in one case its position was recorded at $\sigma_{t}=15.85 \mathrm{~kg} / \mathrm{m}^{3}$.

Location of the suboxic zone upper boundary defined by the oxygen isoline $10 \mu \mathrm{M}$ is characterized by spatial and temporal variability. In the NWS region where four expeditions were carried out in 2009-2013, the oxygen isoline $10 \mu \mathrm{M}$ was located within the $\sigma_{t}=15.6-15.7 \mathrm{~kg} / \mathrm{m}^{3}$, regardless of the season. In the deepsea region, in November, 2013 the oxygen isoline $10 \mu \mathrm{M}$ was located on the 
$\sigma_{t}=15.7 \mathrm{~kg} / \mathrm{m}^{3}$, whereas in November, 2015 it was much higher - on the $\sigma_{t}=$ $=15.35 \mathrm{~kg} / \mathrm{m}^{3}$. Variation of position the oxygen isoline $10 \mu \mathrm{M}$ observed during 1995-2015 provides no grounds for assessing unambiguously alteration of the suboxic zone thickness in the central part of the sea.

During last 20 years no drastic increase of the sulfide content took place in the Black Sea waters within the depths 1750-2000 m.

It seems reasonable to continue investigations of the suboxic zone and, for this purpose, to carry out a few stations on the continental shelf edge. At that the $\sigma_{t}=$ $=16.1-16.2 \mathrm{~kg} / \mathrm{m}^{3}$ should be located in the bottom layer. The sea depth in the points of such stations should be about 150-170 m. Rather flat continental slope to the south off the Cape Tarkhankut or to the south off the Kerch Strait is assumed to be a convenient region for such an experiment.

\section{REFERENCES}

1. Bezborodov, A.A., 1990. Svyaz' Granitsy Serovodorodnoy Zony s Plotnostnoy Strukturoy Vod v Chernom More [Relationship of the Hydrogen Sulfide Boundary and Density Structure of the Black Sea Waters]. Reports of the National Academy of Sciences of the Ukrainian SSR, $B$, (12), pp. 3-6 (in Russian).

2. Vinogradov, M.E. and Nalbandov, Y.R., 1990. Effect of Changes in Water Density on the Profiles of Physicochemical and Biological Characteristics in the Pelagic Ecosystem of the Black Sea. Oceanology, 30(5), pp. 567-573.

3. Codispoti, L.A., Friederich, G.E., Murray, J.W. and Sakamoto, C.M., 1991. Chemical Variability in the Black Sea: Implications of Continuous Vertical Profiles that Penetrated the Oxic/Anoxic Interface. Deep Sea Research Part A. Oceanographic Research Papers, [e-journal] 38(suppl. 2), pp. S691-S710. https://doi.org/10.1016/S0198-0149(10)80004-4

4. Murray, J.W., Codispoti, L.A. and Friederich, G.E., 1995. Oxidation-Reduction Environments: The Suboxic Zone in the Black Sea. In: Chin Pao Huang, Charles R. O'Melia, James J. Morgan, eds., 1995. Aquatic Chemistry: Interfacial and Interspecies Processes. Advances in Chemistry Series. Vol. 244. Washington, DC: American Chemical Society, pp. 157-176.

5. Eremeev, V.N., Konovalov, S.K. and Romanov, A.S., 1997. Investigation of the Formation of Vertical Structure of Biogenic Element Fields in the Black Sea, Using the Method of Spatial Isopicnic Analysis. Physical Oceanography, 8(6), pp. 369-440.

6. Konovalov, S.K. and Murray, J.W., 2001. Variations in the Chemistry of the Black Sea on a Time Scale of Decades (1960-1995). Journal of Marine Systems, [e-journal] 31(1-3), pp. 217-243. https://doi.org/10.1016/S0924-7963(01)00054-9

7. Yakushev, E.V., Lukashev, Yu.F., Chasovnikov, V.K. and Chzhu, V.P., 2002. Sovremennoe Predstavlenie o Vertikal'noy Gidrokhimicheskoy Strukture Redoks-Zony Chernogo Morya [Modern Notion of Redox Zone Vertical Hydrochemical Structure in the Black Sea]. In: A. G. Zatsepin and M. V. Flint, eds., 2002. Kompleksnye Issledovaniya Severo-Vostochnoy Chasti Chernogo Morya [Multidisciplinary Investigations of the Northeast Part of the Black Sea]. Moscow: Nauka, pp. 119-132 (in Russian).

8. Sapozhnikov, V.V. and Sapozhnikov, M.V., 2002. Vertical Distribution of Principal Nutrients in the Black Sea. Oceanology, 42(6), pp. 789-795.

9. Konovalov, S.K., Murray, J.W. and Luther III, G.W., 2005. Basic Processes of the Black Sea Biogeochemistry. Oceanography, [e-journal] 18(2), pp.24-35. https://doi.org/10.5670/oceanog.2005.39 
10. Eremeev, V.N. and Konovalov, S.K., 2006. K Voprosu o Formirovanii Byudzheta i Zakonomernostyakh Raspredeleniya Kisloroda i Serovodoroda v Vodakh Chernogo Morya [On the Budget and the Distribution of Oxygen and Sulfide in the Black Sea Water]. Marine Ekological Journal = Morskoj Ehkologicheskij Zhurnal, 5(3), pp. 5-30 (in Russian).

11. Konovalov, S.K. and Eremeev, V.N., 2012. Regional'nye Osobennosti, Ustoychivost' i Evolyutsiya Biogeokhimicheskoy Struktury Vod Chernogo Morya [Regional Features, Stability, and Evolution of Biochemical Structure of the Black Sea Waters]. In: V. N. Eremeev, S. K. Konovalov, eds., 2012. Ustoychivost' i Evolyutsiya Okeanologicheskikh Kharakteristik Ekosistemy Chernogo Morya [Stability and Evolution of Oceanological Characteristics of the Black Sea Ecosystems]. Sevastopol: EKOSI-Gidrofizika, pp. 273-299 (in Russian).

12. Tuğrul, S., Murray, J.W., Friederich, G.E. and Salihoğlu, İ., 2014. Spatial and Temporal Variability in the Chemical Properties of the Oxic and Suboxic Layers of the Black Sea. Journal of Marine Systems, [e-journal] 135, pp. 29-43. https://doi.org/10.1016/j.jmarsys.2013.09.008

13. Eremeeva, L.V., Romanov, A.S., Ovsjanyj, E.I., Dolotov, V.V. and Konovalov, S.K., 1995. Gidrokhimicheskie Issledovaniya v 33-m Reyse Nauchno-Issledovaiel'skogo Sudna "Professor Kolesnikov" [Hydro-Chemical Studies in the 33 ${ }^{\text {rd }}$ Cruise of R/V "Professor Kolesnikov"]. NAN Ukrainy working paper. Sevastopol: MHI, 43 p. (in Russian).

14. Kontrat'ev, S.I., Romanov, A.S. and Vnukov, Yu.L., 2007. Osobennosti Raspredeleniya Gidrokhimicheskikh Kharakteristik v Rayone Materikovogo Sklona Severo-Zapadnoy Chasti Chernogo Morya [Peculiarities of Distribution of Hydrochemical Characteristics in the Region of the Continental Slope of the North-Western Black Sea]. Morskoy Gidrofizicheskiy Zhurnal, (5), pp. 96-106 (in Russian).

15. Kontrat'ev, S.I. and Vnukov, Yu.L., 1999. Struktura Vertikal'nogo Raspredeleniya Kisloroda v Vodakh Priust'evogo Vzmor'ya Dunaya v Osenniy Period 1997 g. [Structure of the Oxygen Vertical Distribution in the Danube Mouth Coastal Waters in Autumn, 1997]. In: MHI, 1999. Ekologicheskaya Bezopasnost' Pribrezhnoi i Shel'fovoi Zon i Kompleksnoe Ispol'zovanie Resursov Shel'fa [Ecological Safety of Coastal and Shelf Zones and Comprehensive Use of Shelf Resources]. Sevastopol: MHI NANU, pp. 125-137 (in Russian).

16. Gevorgiz, N.S., Eremeeva, L.V. and Kondrat'ev, S.I., 1999. Vliyanie Apvellinga na Gidrokhimicheskiy Rezhim [Influence of Upwelling on Hydrochemical Conditions]. In: V. A. Ivanov, S. V. Goshovskiy, eds., 1999. Prirodnye Usloviya Vzmor'ya Reki Dunay i Ostrova Zmeinyy: Sovremennoe Sostoyanie Ekosistemy [Natural Conditions of the Danube Mouth and the Zmeiny Island Coastal Waters: Present State of the Ecosystem]. Sevastopol: MHI NANU, pp. 160-173 (in Russian).

17. Kondratyev, S.I., 2014. Osobennosti Prostranstvennogo Raspredeleniya Kisloroda v Vodakh Priust'evogo Vzmor'ya Dunaya v 1997-2010 Godakh [Features of Oxygen Spatial Distribution in the Coastal Waters of the Danube Region in 1997-2010]. Morskoy Gidrofizicheskiy Zhurnal, (3), pp. 60-76 (in Russian).

18. Bordovskiy, O.K. and Ivanenkov, V.N. eds., 1978. Metody Gidrokhimicheskikh Issledovaniy Okeana [Methods of Hydrochemical Ocean Studies]. Moscow: Nauka, 272 p. Available at: https://www.geo-fund.am/files/library/1/15278538607187.pdf [Accessed: 02 September 2018] (in Russian).

19. Kubryakov, A.A. and Stanichny, S.V., 2015. Seasonal and Interannual Variability of the Black Sea Eddies and its Dependence on Characteristics of the Large-Scale Circulation. Deep Sea Research Part I: Oceanographic Research Papers, [e-journal] 97, pp. 80-91. https://doi.org/10.1016/j.dsr.2014.12.002 
20. Shapiro, G.I., Stanichny, S.V. and Stanychna, R.R., 2010. Anatomy of Shelf-Deep Sea Exchanges by a Mesoscale Eddy in the North West Black Sea as Derived from Remotely Sensed Data. Remote Sensing of Environment, [e-journal] 114(4), pp. 867-875. https://doi.org/10.1016/j.rse.2009.11.020

21. Zhou, F., Shapiro, G. and Wobus, F., 2014. Cross-Shelf Exchange in the Northwestern Black Sea. Journal of Geophysical Research: Oceans, [e-journal] 119(4), pp. 2143-2164. https://doi.org/10.1002/2013JC009484

22. Pakhomova, S., Vinogradova, E., Shtereva, G. and Kostyleva, A., 2009. Izmenchivost' Gidrokhimicheskoy Struktury Redoks-Sloya Chernogo Morya [Variability of Hydrochemical Structure of Redox Layer of the Black Sea]. In: Geologiya Morey i Okeanov: Materialy XVIII Mezhdunarodnoy Nauchnoy Konferentsii (Shkoly) po Morskoy Geologii, Moskva, 16-20 noyabrya $2009 \mathrm{~g}$ [Geology of Seas and Oceans: Proceedings of the XVIII International Scientific Conference (School) on Marine Geology, November 16-20, 2009]. Moscow: GEOS, 2009. Vol. 4, pp. 122-125 (in Russian).

23. Stanev, E.V., He, Y., Staneva, J. and Yakushev, E., 2014. Mixing in the Black Sea Detected from the Temporal and Spatial Variability of Oxygen and Sulfide - Argo Float Observations and Numerical Modelling. Biogeosciences, [e-journal] 11(20), pp. 5707-5732. https://doi.org/10.5194/bg-11-5707-2014

24. Stanev, E.V., Poulain, P.-M., Grayek, S., Johnson, K.S., Claustre, H. and Murray, J.W., 2018. Understanding the Dynamics of the Oxic-Anoxic Interface in the Black Sea. Geophysical Research Letters, [e-journal] 45(2), pp. 1-8. https://doi.org/10.1002/2017GL076206

25. Ivanov, V.A. and Belokopytov, V.N., 2013. Oceanography of the Black Sea. Sevastopol: ECOSI-Gidrofizika, 210 p. Available at:

https://www.researchgate.net/publication/236853664_Ivanov_VA_Belokopytov_VN_Oceanogr aphy_of_the_Black_Sea_National_Academy_of_Sciences_of_Ukraine_Marine_Hydrophysical_ Institute_Sevastopol_210_p [Accessed: 06.09.2018].

About the authors:

Sergey I. Kondratev - Senior Research Associate, Department of the Sea Biogeochemistry, FSBSI MHI (2 Kapitanskaya Str., Sevastopol, 299011, Russian Federation), Ph.D. (Chem. Sci.), ORCID ID: 0000-0002-2049-7750, skondratt@mail.ru

Anna V. Vidnichuk - Senior Engineer, Post-graduate, Department of the Sea Biogeochemistry, FSBSI MHI (2 Kapitanskaya Str., Sevastopol, 299011, Russian Federation), anna_vidnichuk@mhiras.ru

Contribution of the co-authors:

Sergey I. Kondratev - statement of the investigation tasks and problems, analysis of the scientific literature data, data analysis and interpretation, discussion of the investigation results, preparation of the paper text

Anna V. Vidnichuk - analysis of scientific literature on the problem under study, data accumulation and systematization, construction of the graphs and figures, discussion of the investigation results

All the authors have read and approved the final manuscript.

The authors declare that they have no conflict of interests. 